\title{
LA IMAGEN DE NUESTRA SEÑORA DE LA PEÑA DE FRANCIA. PUERTO DE LA CRUZ (TENERIFE). EXAMEN Y TRATAMIENTO
}

\author{
Silvano Acosta Jordán* \\ Clementina Calero Ruiz**
}

\section{RESUMEN}

La restauración de la escultura de Nuestra Señora de la Peña de Francia, en la iglesia homónima del Puerto de la Cruz, fue realizada entre julio y octubre de 2017, dentro de los convenios establecidos entre el Cabildo Insular de Tenerife y la diócesis Nivariense para la conservación y restauración de su patrimonio histórico-artístico. El trabajo se inició con un estudio radiográfico, que ha sido fundamental para entender su factura, así como las modificaciones a que ha estado sujeta la escultura durante siglos. Las muestras tanto de soporte como de policromía fueron muy bien seleccionadas, para con un mínimo número de ellas obtener, tras los análisis pertinentes, resultados completos, tanto de la naturaleza del soporte original como de los estratos de preparación y color. A esto le sumamos un importante acopio de material gráfico y fotográfico del estado inicial con descripción de las patologías y de los procesos de actuación sobre ella. Finalmente el estudio lo completamos con una investigación documental, que le aporta a este trabajo de restauración algunos aspectos inéditos relacionados con su indumentaria, que viene a enriquecer una parcela no siempre estudiada, aunque directamente relacionada con la escultura y su devoción.

Palabras clave: conservación-restauración, escultura policromada, Peña de Francia, Puerto de la Cruz.

\author{
THE SCULPTURE OF NUESTRA SEÑORA DE LA PEÑA DE FRANCIA. \\ PUERTO DE LA CRUZ (TENERIFE). STUDIES AND TREATMENTS
}

\section{Abstract}

The restoration of Nuestra Señora de la Peña de Francia was realized between July and October of 2017. This work was supported by scientific research using radiography and pigment analysis. The sculpture was studied and further on materials and former interventions were dated. Finally we provided some unpublished information to complete the art-historical aspects of the statue.

Keywords: conservation and restoration, polychrome sculpture, Peńa de Francia, Puerto de la Cruz. 


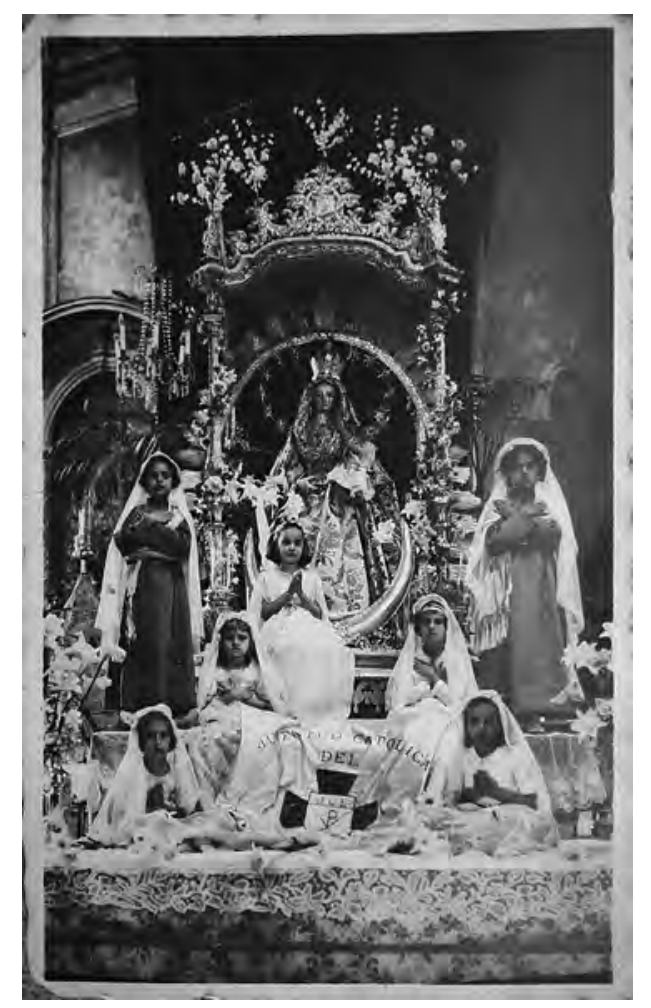

Foto 1. Nuestra Señora de la Peña de Francia. c. 1940.

El culto a Nuestra Señora de la Peña es relativamente importante tanto en Canarias como en la Península Ibérica e Hispanoamérica, y su historia se origina tras el hallazgo de la imagen por Simón Vela en la Peña de Francia (Salamanca), el 19 de mayo de $1434^{1}$. Su tipología es muy variada, pues no se adapta a un modelo único, ya que María puede aparecer tanto de pie como sedente, con el Niño en sus brazos, que a veces parece acariciar a su madre y otras le entrega una fruta. Curiosamente,

\footnotetext{
* Licenciado en Bellas Artes. Conservador-restaurador de obras de arte. silvanoacosta@ ymail.com.

** Profesora titular de Historia del Arte Moderno. Departamento de Historia del Arte y Filosofía. Sección de Geografía e Historia. Facultad de Humanidades. Universidad de La Laguna. ccalero@ull.edu.es.

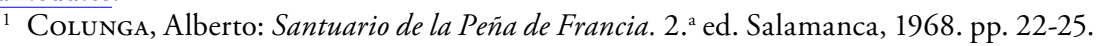
Vasco Parra, Mateo: Historia de la invención y milagros de Nuestra Señora de la Peña de Francia. Madrid, 1973.
} 


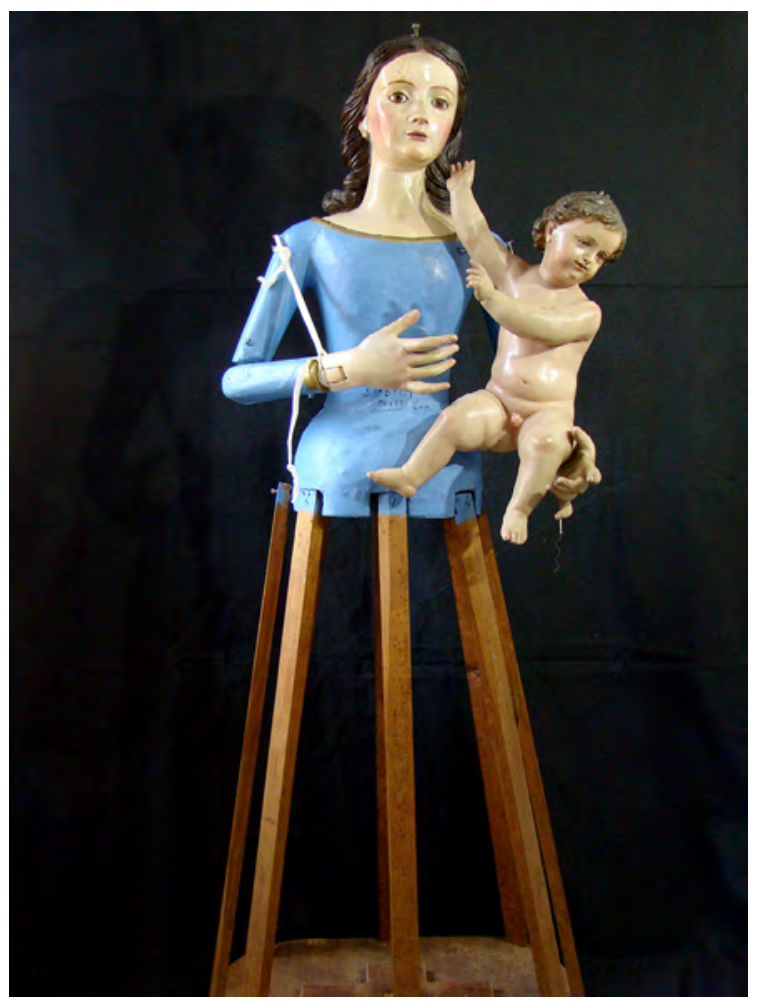

Foto 2. Imagen de Nuestra Señora de la Peña de Francia previa a la restauración.

la que se venera en su santuario salmantino es negra ${ }^{2}$, mientras que ninguna de las localizadas en Canarias presenta la tez morena ${ }^{3}$.

La imagen objeto de nuestro estudio se localiza en su iglesia homónima, aunque en el Puerto de la Cruz también recibe culto bajo el título de Nuestra Señora de la Peñita en otro templo, ubicado en el barrio de La Ranilla. En este segundo caso se trata de un facsímil en madera policromada y estofada de la patrona de Fuerteventura $^{4}$, fechada con anterioridad al año 1752 y donada por los fundadores de su ermita, Gregorio Martín de Aguiar y su primera mujer, María de Horta 5 .

2 Trens, Manuel: María. Iconografía de la Virgen en el arte español. Madrid, 1946. p. 255.

${ }^{3}$ Hernández Díaz, Patricio: "Iconografía de la Peña de Francia en Canarias», Actas de las II Jornadas de Historia de Lanzarote y Fuerteventura, tomo II, Arrecife, 1990. pp. 221-231.

${ }^{4}$ Cerdeña Ruiz, Rosario: La imagen de la Virgen de la Peña, Cabildo de Fuerteventura, 2008. pp. 33-36.

5 Calero Ruiz, Clementina: «La ermita de Nuestra Señora de la Peñita», Libro Homenaje al profesor Telesforo Bravo, vol. II, 1991. pp. 137-146. 
El grupo escultórico de Nuestra Señora de la Peña de Francia se compone de una escultura principal de candelero, dedicada a la Virgen, y otra secundaria de bulto, que representa al Niño Jesús, ambas vinculadas entre sí por anclajes metálicos. Su composición es barroca y tradicional, respondiendo a la tipología que conocemos popularmente como imágenes de vestir. Por extensión, el vestido en estas esculturas, en particular en la que nos ocupa, es una parte consustancial de su plástica. Su atuendo se remata con aditamentos de plata en su color y sobredorada, completándose con algunas joyas de uso civil de oro, plata y piedras preciosas, mayoritariamente lucidas durante los recorridos procesionales.

Su forma actual es el resultado de varias intervenciones y fruto de pérdidas, añadidos y reparaciones, que se han ido produciendo con el paso de los siglos, aportándole el aspecto que presenta hoy en día. En este sentido, debemos considerar las vicisitudes de un culto y devoción constante desde el siglo $\mathrm{XVII}^{6}$, donde se perciben momentos de gran riqueza y hondo arraigo, combinados con otros, donde quedó patente el desapego y el olvido, como ocurrió a partir de los ańos setenta del pasado siglo. Estas circunstancias han quedado reflejadas en su conjunto, lo que ha determinado su concepción y expresión actual. La transformación de imágenes de culto, de la que no es ajena nuestra escultura, ha sido una constante en la historia del arte y de las devociones, y solía ser una operación oculta, efectuada generalmente por algún artista, que en ocasiones dejaba constancia de la labor con su firma ${ }^{7}$. Otras veces se convertía en una actuación improvisada, anónima y urgente, que llanamente remendaba para dotar a la escultura del uso ritual para el que fue creada ${ }^{8}$.

Gracias a un retrato de vera efigie que estuvo inserto en el antiguo estandarte de la cofradía ${ }^{9}$, podemos conocer y fundamentar los cambios de composición que afectan al grupo escultórico y que no se corresponden con el estado actual. Lo mismo expresa la representación de la Virgen María, que introduce elementos ajenos o desaparecidos de su indumentaria, caso concreto del cetro que porta en la mano. Otro grupo de alteraciones de concepto las encontramos en la mutilación y dispersión de su ajuar de plata, concretamente en lo referente a sus antiguas andas procesionales de baldaquino, que se conservaron relativamente completas hasta los años cincuenta del pasado siglo.

${ }^{6}$ «De la imagen y sus propiedades se encargaba su Hermandad la cual se fundó en el mes de noviembre de 1668, siendo cura párroco el Dr. Don Agustín de la Rosa, y sus estatutos se reglamentaron en noviembre de 1697, los cuales fueron pasados a limpio a un libro forrado en pergamino regalo de don Antonio Llanos del Castillo en 1771». Ver Ruiz Álvarez, Antonio: «Estampas Históricas del Puerto de la Cruz», La Tarde, Santa Cruz de Tenerife, 19 de agosto de 1949. p. 3.

${ }^{7}$ La escultura muestra una firma autógrafa, donde puede leerse: «LA RESTAURÓ E de León D. 31-8-69 Puerto Cruz». Esta firma se documenta fotográficamente.

${ }^{8}$ Así han llegado hasta hoy en día infinidad de esculturas, acribilladas por clavos, alfileres y grapas. Otras, descarnadas o mutiladas hasta el extremo de no ser reconocibles o mostrar tal inestabilidad que se desaconseja su exposición pública.

${ }^{9}$ Desafortunadamente esta pintura fue traspasada a un lienzo, desvinculándose de su posición original, y actualmente se expone descontextualizada en el museo parroquial, en una localización inaccesible. 


\section{HISTORIA MATERIAL}

En el grupo escultórico hemos documentado cuatro restauraciones. La primera se evidencia únicamente a través de medios físico-químicos, realizándose probablemente en torno a la segunda mitad del siglo XVIII, es anónima y no ha quedado registrada en ninguno de los documentos consultados hasta el momento. Por las analíticas y las evidencias materiales es lícito pensar que esta intervención transformó los brazos y las articulaciones de los hombros, culminándose con un repinte superficial a base de óxido de hierro.

La segunda fue muy profunda y ha quedado bien documentada ${ }^{10}$, pues transformó toda la estructura y composición del candelero con añadidos de materiales heterogéneos, entre los que están presentes fragmentos de madera, yeso, trapos y cartón. El busto y los brazos, pintados originariamente de color rojo, fueron parcialmente decapados y posteriormente repolicromados de azul índigo. Gracias al estudio químico de una micromuestra pudimos confirmar la presencia de blanco de zinc, pigmento utilizado a partir de la segunda mitad del siglo XIx. Este dato técnico coincide perfectamente con las etiquetas halladas en la pieza, que ponen fecha exacta a esta intervención. Al respecto, tras la refundación de la cofradía en 1870, sus miembros trataron de mejorar el aspecto de la imagen, que desde 1851 había quedado desprotegida, por lo que el nuevo hermano mayor, don José Hernández Barrios, con el visto bueno del párroco don Domingo Brito Salazar, decide el 8 de febrero de 1878 enviarla a Barcelona, pues, según comentan: «No se encontró en la isla ninguna persona capaz de ejecutar el delicado trabajo que se encomendaba» ${ }^{11}$.

La Virgen fue embarcada rumbo a la ciudad condal y recibida por el Dr. don Justo Espinosa de los Monteros y $\mathrm{Mesa}^{12}$, un médico pediatra portuense que residía en Barcelona. Él se hizo cargo de todos los gastos derivados de la restauración y de sus traslados, devolviéndola a tiempo, antes de su muerte, para que llegara «perfectamente restaurada» en los primeros días del mes de agosto de 1878. Eso es al menos lo que recogieron los periódicos de la época; sin embargo, se plantea una duda. ¿Por qué se vuelve a intervenir nuevamente en abril de 1879 , a solo ocho meses de haber sido entregada, y esta vez por el escultor Perdigón Oramas? Estas preguntas podrían encontrar respuesta en supuestas incorrecciones técnicas o simplemente pudo haber sido entregada sin acabar.

${ }^{10}$ Se hallaron dos etiquetas impresas en papel, una en la espalda y otra bajo la corona del candelero donde se lee lo siguiente: «Restaurada en Barcelona en 1878, siendo Cura párroco propietario el SR. D. Domingo Brito y salazar y Mayordomo D. José hernandez barrios».

${ }^{11}$ Ruiz Álvarez, Antonio: «Estampas históricas del Puerto de la Cruz». La Tarde, Santa Cruz de Tenerife, 19 de agosto de 1949. p. 3. Ruiz Álvarez, Antonio: "En torno a la imagen de la Peña de Francia”. La Tarde, Santa Cruz de Tenerife, 17 de agosto de 1951.

12 Ruiz Álvarez, Antonio: «El Dr. Don Justo Espinosa de los Monteros». Revista de Historia Canaria, La Laguna, 1956. pp. 88-92. 
La restauración de Nicolás Perdigón Oramas ${ }^{13}$ ocupa el tercer lugar y es la que termina de transformar el conjunto, centrando gran parte su actuación en la cabeza, especialmente en el pelo, que solía componer con madera, estopa y yeso, pues hasta esa época la imagen procesionaba con peluca de pelo natura ${ }^{14}$. Este escultor le coloca ojos de vidrio y le modifica las manos para finalmente repolicromar el busto, brazos y antebrazos, esta vez de azul de Prusia con blanco de zinc. Suponemos que en este proceso pudo haber desaparecido el Niño Jesús original, sustituyéndose por el actual ${ }^{15}$. Esta pequeña escultura fue intervenida a nivel de soporte en dos de los dedos de la mano derecha y repolicromada enteramente. Así se mantuvo y procesionó hasta 1969, año en que se vuelve a intervenir, posiblemente a instancias de la comunidad agustina.

La cuarta restauración la firmó en la cintura de la Virgen el escultor Ezequiel de León Domínguez. Su actuación se centró especialmente en las manos y en el cuello, por esas fechas ya muy erosionados por los anillos y zarcillos. También trabajó en el rostro, retocando algunas fisuras en la frente y en los parpados, que durante un tiempo lucieron pestañas postizas. Además, sustituyó el candelero anterior por tablas de pino y modificó la articulación de uno de los codos. Finalmente repintó el busto, antebrazos y brazos de azul ultramar artificial. El Niño recibió un repinte integral, del que únicamente quedó libre -por suerte- la cabeza.

\section{ANÁLISIS DEL ESTADO DE CONSERVACIÓN}

Una primera aproximación a la escultura la efectuamos el 31 de agosto de 2016, momento que se aprovechó para observar su estado de conservación y tomar las primeras imágenes del conjunto. En este punto nos llamaron la atención las numerosas reparaciones de urgencia, la mayoría a base de fijaciones improvisadas, para que la escultura no perdiera la expresión postural. El estudio detallado del soporte determinó una composición mixta de maderas, parte de ellas originales y otras introducidas durante las restauraciones. Se presentaba muy inestable al estar asociado con materias heterogéneas como yeso, pasta de papel, estopa, clavos, fragmentos de

${ }^{13}$ El análisis de la segunda parte de la inscripción hallada en la etiqueta dice: «Reformada en La Orotava en abril de 1879, por NPO». Alude al escultor-restaurador Nicolás Perdigón Oramas, quien desarrolló su trabajo principalmente en el valle de La Orotava. Para la parroquial portuense restauró, entre otras, la escultura del Nazareno.

${ }^{14}$ Loinaz Muñoz, Dulce María: Un verano en Tenerife. Cap. XXIII, El Puerto de la Cruz. Edit.: Viceconsejería de Cultura y Deportes del Gobierno de Canarias. 1992. p. 316: «cierto presbítero nombrado don Nicolás Heredia, observando un día que los cabellos de Nuestra Seńora se habían arruinado, no vaciló en subir al púlpito y desde allí pedir a las jóvenes del Puerto la ofrenda de sus cabelleras, a fin de remediar a la Patrona su necesidad».

${ }^{15}$ El Niño Jesús parece ser un préstamo o adición posterior. Se trata de una bella escultura infantil plena de gracia y movimiento, con un tratamiento plástico de correcta talla, proporción y delicado pulimento. Estos aspectos nos refieren a trabajos italianos o de la Baja Andalucía, sin poder seriamente precisar una escuela concreta. 
maderas e incluso textiles muy alterados por hongos y por corrosión metálica. La mayoría de los daños estructurales estaban ocultos y únicamente eran perceptibles mediante radiografías. Las articulaciones de la escultura principal estaban rotas y se habían estabilizado con alambres, tornillos y cintas de algodón para impedir su caída. La inestabilidad era muy visible en el candelero, que se había reparado provisionalmente con madera de pino y chapa marina, uniéndose a la corona de la cadera con improvisadas fijaciones metálicas. El Niño Jesús había perdido dos dedos de la mano izquierda y dos de la derecha. Parte de ellos habían sido reconstruidos con yeso o tallados burdamente en madera. Muchas patologías asociadas al soporte se relacionaban con actuaciones históricas, pues cada episodio de intervención remendaba al anterior sin que ninguno llegara a resolver sus defectos.

La policromía original estaba completamente oculta y maquillada con recrecidos de yeso y repintes muy gruesos, localizándose en el busto y en los brazos, las zonas más alteradas. Otro tanto ocurría con las carnaciones originales del rostro, cuello y manos de la Virgen, intervenidas en distintas épocas, unas veces recreando una nueva fisonomía y otras ocultando daños por desgaste y mal uso. Esto se relaciona con la costumbre de usar alfileres, clavos y hasta grapas para fijar la vestimenta o las joyas ${ }^{16}$. A las alteraciones por uso y envejecimiento se añadieron las generadas por las restauraciones, que comportaron la destrucción consciente de partes de ella. La presencia de materiales altamente inestables e higroscópicos como el yeso o el papel causó otras patologías asociadas a las ya existentes.

El antiguo repolicromado del rostro de la Virgen es estable y de buena calidad, posiblemente realizado antes del siglo xix. En el caso del Niño Jesús estas actuaciones eran más modernas, menos drásticas, pero de peor calidad, superponiéndose la labor de Perdigón Oramas y la de Ezequiel de León. El examen con luz UV y lupa de exploración dermatológica reveló en superficie importantes retoques antiguos, que afectaban al busto, cuello, parte del rostro, cabeza y manos en el caso de la Virgen ${ }^{17}$. La escultura del Niño se descubrió prácticamente repintada sobre repolicromados de la restauración de 1969. Las carnaciones en ambas piezas se percibían mates, empañadas y sucias, veladas por depósitos grasos, procedentes de las manos y del hollín de las velas que antiguamente ardían en el templo.

16 En marzo de 2015 se celebró la primera jornada arciprestal de hermandades y cofradías del arciprestazgo de La Orotava, donde se desarrollaron aspectos sobre la conservación y legislación de los bienes muebles de la Iglesia. A pesar de estas campañas de concienciación sobre el cuidado y manipulación, malas prácticas siguen vigentes en camareras y personal colaborador de las parroquias, pues no terminan de entender que están actuando sobre bienes sensibles; en definitiva, sobre obras de arte, aparte de imágenes de devoción.

${ }_{17}$ La causa de estos daños se encuentra en la colocación de joyas sin prevenir ningún material aislante entre los metales y las policromías. Últimamente conscientes de la erosión que las joyas causan en las esculturas, se empiezan a recubrir anillos y collares con materiales aislantes, permitiendo la segura presentación de estos adornos y exvotos. 


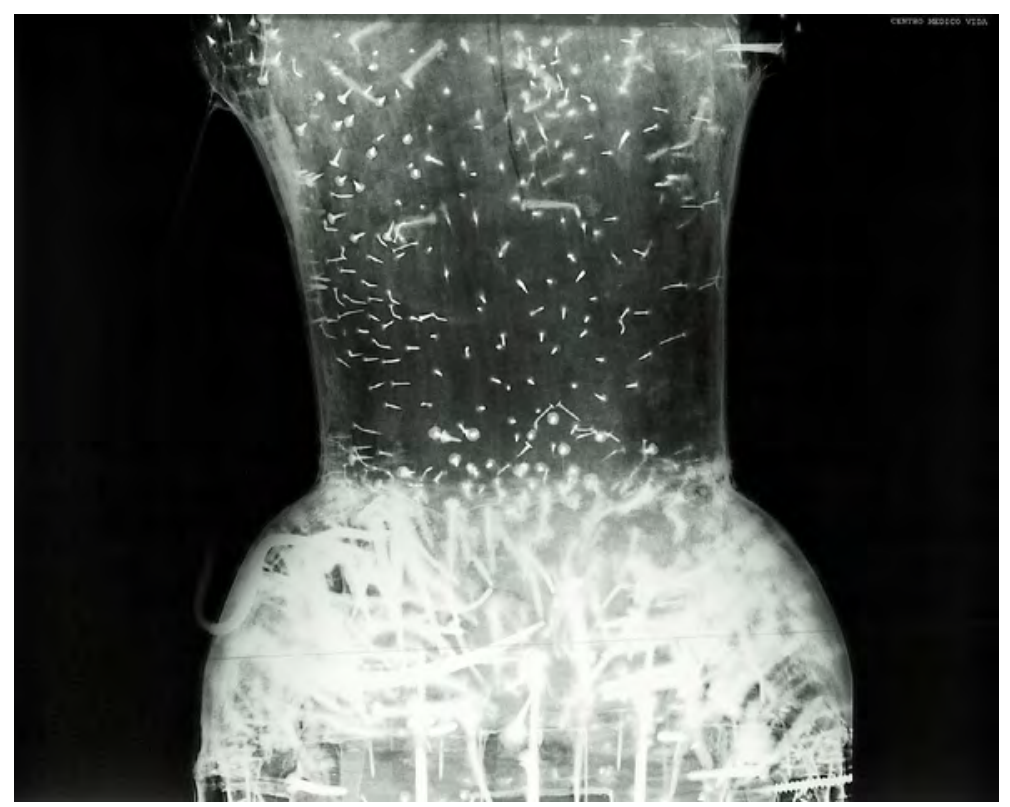

Foto 3. Radiografía del torso.

\section{ESTUDIOS FÍSICO-QUÍMICOS}

Antes de proceder a la restauración actual fue preciso profundizar en sus patologías, para lo cual nos apoyamos en el estudio radiográfico ${ }^{18}$. Su descripción mediante seis placas puso de manifiesto la estructura interna y los numerosos añadidos, dejando visibles características desconocidas hasta el momento. En el caso de la Virgen una de las alteraciones observadas fue la mutilación y el bloqueo de los hombros, que originalmente eran móviles, supuestamente mediante una articulación de galleta. Otras imágenes mostraban el busto claveteado con tachuelas de zapatero, que trababan una gruesa masa de yeso y pasta de papel, así como el aumento de volumen en la cadera con todo tipo de desechos clavados entre sí. Especial interés posee la radiografía de la parte superior, donde queda documentada la fisonomía subyacente de la cabeza original con los añadidos de la cabellera actual y la excavación de las cavidades oculares para colocarle los ojos de vidrio.

${ }_{18}$ El estudio radiográfico se realizó en el Centro Médico Vida, Tenerife, en un equipo Toshiba Radrex $50 \mathrm{KW}$. Modelo MRAD-A50S/G5. Datos técnicos de la emisión de las seis placas: $80 \mathrm{Kv} / / 320 \mathrm{ma} / / 0.500 \mathrm{mAs} / /$ Foco grueso. Formato de placa: $43 \times 35 \mathrm{~cm}$. Imagen digital. 
La radiografía del Niño muestra una textura de soporte homogéneo sin fisuras y aporta datos sobre la tecnología de construcción, pudiéndose observar la unión de piezas a tope sin expresar ningún sistema de ensamblaje o refuerzos metálicos. En la imagen son claramente visibles las pérdidas de soporte original con ańadidos de yeso y anclajes metálicos, que le sirven de vínculo con la escultura principal.

Las transformaciones operadas en la escultura de la Virgen han sido de tal magnitud que en un principio fue del todo imposible acceder al soporte original sin dañar la policromía. Por esta razón la toma de esta muestra se postergó hasta tener acceso a una zona lo suficientemente representativa y segura para su extracción, que finalmente se localizó en el interior del busto. El estudio del soporte se hizo mediante observación microscópica de sus características morfológicas en relación con patrones anatómicos de especies botánicas de varios tipos de laureles. El resultado de este análisis demuestra la utilización de un tipo de madera procedente de los bosques de laurisilva, Apollonias barbujana, el barbusano. La identificación del soporte ha sido determinante a la hora de descartar la antigua atribución a escuelas italianas ${ }^{19}$, fijando la factura de la obra en Canarias. Por desgracia, por razones de escaso presupuesto no se pudieron realizar estudios dendocronológicos, que nos hubieran aportado información más precisa sobre la antigüedad del soporte.

También se realizó el estudio de una muestra bien seleccionada de policromía, que comportara toda la secuencia de capas desde su origen, para conocer las características morfológicas y químicas de sus componentes. Se concluye en él que la superposición estratificada de policromías es coincidente desde el punto de vista químico con las fechas halladas en las etiquetas. La interpretación de este análisis fue determinante para localizar e identificar los estratos originales, lo que garantizó las decisiones posteriores.

Reproducimos en el texto el resultado e interpretación de esta analítica realizada por el doctor en ciencias químicas don Enrique Parra Grego, dado el interés que para nuestro trabajo posee. Las técnicas empleadas son las habituales en este tipo de análisis y consisten en cromatografía de gases acoplada a espectrometría de masas para la identificación de sustancias lipófilas; microscopía electrónica de barrido/análisis elemental por energía dispersiva de rayos X (MEB/ EDX), utilizada en el estudio e identificación de los pigmentos presentes en las policromías; espectroscopía infrarroja (IR) aplicada para el estudio de las preparaciones y de sustancias presentes en barnices o recubrimientos; finalmente, estudio de micromuestras mediante microscopía óptica por reflexión y transmisión con luz polarizada para la visualización de superposiciones de capas pictóricas y como estudio preliminar de pigmentos aglutinantes y barnices.

${ }_{19}$ Esta observación iniciada por Ruiz Álvarez fue adoptada por otros investigadores posteriores, lo que ha llevado a la confusión y a interpretaciones erróneas en el tiempo. En este sentido, el uso de medios físico-químicos de análisis ayuda una vez más a la historia del arte a determinar la procedencia y escuela de una obra artística. 


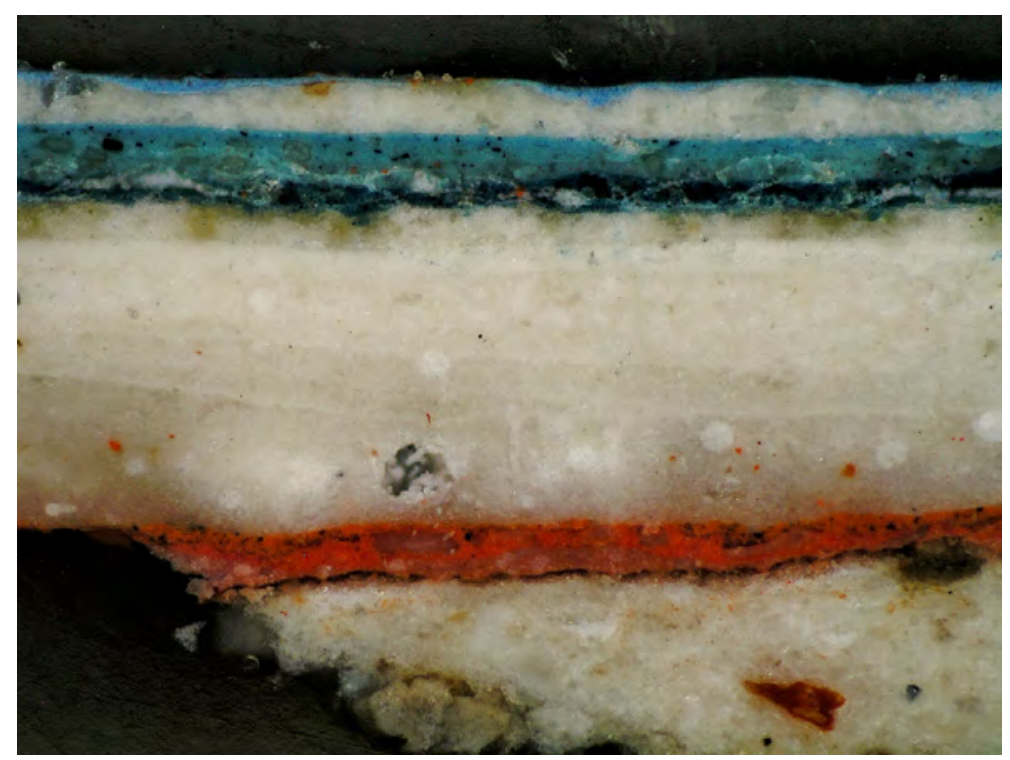

Foto 4. Secuencia estratigráfica.

\begin{tabular}{|c|c|c|c|c|}
\hline \multicolumn{5}{|c|}{ FRS-1: COLOR AZUL DEL ANTEBRAZO DERECHO } \\
\hline $\begin{array}{l}\text { CAPA } \\
\text { N. }{ }^{\circ}\end{array}$ & COLOR & $\begin{array}{c}\text { ESPESOR } \\
(\mu)\end{array}$ & Pigmentos & Aglutinantes \\
\hline 1 & blanco & 300 & $\begin{array}{l}\text { anhidrita, yeso, arcillas (tr.), óxidos de hierro } \\
\text { (tr.), negro carbón vegetal (tr.), cloruros (tr.) }\end{array}$ & cola animal \\
\hline 2 & blanco & 100 & $\begin{array}{l}\text { anhidrita, yeso, albayalde, arcillas (tr.), óxidos } \\
\text { de hierro (tr.), negro carbón vegetal (tr.), } \\
\text { cloruros (tr.) }\end{array}$ & cola animal \\
\hline 3 & $\begin{array}{l}\text { marrón trans- } \\
\text { lúcido }\end{array}$ & 10 & - & proteína \\
\hline 4 & rojo & 20 & $\begin{array}{l}\text { albayalde (blanco de plomo), calcita, rojo óxido } \\
\text { de hierro }\end{array}$ & proteína \\
\hline 5 & rojo & 10 & $\begin{array}{l}\text { bermellón, minio de plomo, rojo óxido de hierro } \\
\text { (tr.), negro carbón (tr.) }\end{array}$ & proteína \\
\hline 6 & rojo anaranjado & 5 & minio, calcita, rojo óxido de hierro (tr.) & proteína \\
\hline 7 & $\begin{array}{l}\text { blanco (varias } \\
\text { capas) }\end{array}$ & 250 & calcita, arcillas (tr.) & cola animal \\
\hline 8 & azul oscuro & 40 & albayalde, blanco de zinc, calcita, índigo & $\begin{array}{l}\text { aceite secante, resina } \\
\text { diterpénica }\end{array}$ \\
\hline 9 & azul & $20-30$ & albayalde, blanco de zinc, calcita, azul de Prusia & $\begin{array}{l}\text { aceite secante, resina } \\
\text { diterpénica }\end{array}$ \\
\hline 10 & blanco irregular & $0-50$ & yeso, basanita, dolomita (tr.), arcillas (tr.) & cola animal \\
\hline 11 & azul & $10-20$ & $\begin{array}{l}\text { blanco de titanio, yeso, blanco de zinc, ultramar } \\
\text { artificial, albayalde (tr.), sulfato de bario (tr.) }\end{array}$ & $\begin{array}{l}\text { aceite secante, resina } \\
\text { diterpénica }\end{array}$ \\
\hline 12 & translúcido & 5 & yeso, arcillas, oxalato de calcio, calcita (tr.) & resina diterpénica \\
\hline
\end{tabular}


En la muestra encontramos varias policromías superpuestas. La primera es la original. En ella aparece una preparación compuesta de yeso y cola animal, aplicada en varias capas. La superior (capa 2) parece que contiene menos impurezas, presentando un grano más fino que en la capa inferior (capa 1), aunque no se aprecia una división clara entre ellas. No obstante, la capa superior es clara en el microanálisis, ya que contiene algo de albayalde en la mezcla (capa 2). El yeso en ambas capas contiene abundante anhidrita (procedente de la cocción del yeso) y pequeñas cantidades de arcillas y óxidos de hierro, como impurezas naturales más destacables. La preparación termina con una capa aislante de cola animal, con un cierto color marrón (capa 3). Sobre esta base hay tres capas de color rojo (capas 4-6), en las que están presentes diferentes pigmentos. Parece que el conjunto pertenece a la misma ejecución, ya que no se aprecian barnices intermedios y que las capas están bien fundidas unas con las otras. Concluyendo que la técnica aplicada es un temple, posiblemente de huevo.

Lo observado por encima de esto son repolicromías. Hay una primera con estuco de calcita y cola animal (capa 7), que se torna en color azul (capa 8). Esta capa es ya del siglo XIX o posterior, por la presencia de blanco de zinc, cuya técnica es de tipo oleorresinoso. Esta policromía está directamente repintada por otra (capa 9), en la que está presente azul de Prusia. Sobre esta se advierte una preparación constituida por yeso y cola animal (capa 10), volviéndose a policromar con azul ultramar artificial y blanco de titanio (capa 11). Se trata de una policromía del siglo xx o posterior. En la superficie hay restos de un barniz resinoso sucio (capa 12).

En el análisis cromatográfico predomina la proteína de huevo (de las capas de temple rojas) y el aceite de linaza (en las capas oleorresinosas azules) En los estratos superiores aparecen tres tipos de resinas: colofonia, goma laca y sandáraca, que pertenecen a barnices y aglutinantes de las capas modernas de pintura, aunque en esta muestra no se pueden asignar concretamente a ninguna.

\section{TRATAMIENTO}

Una vez analizados e interpretados los informes técnicos se convocó una primera reunión con la presencia de varios miembros de la actual junta directiva de la cofradía de Nuestra Señora de la Peña de Francia, el párroco don Luis Rodríguez de Lucas y la doctora doña Clementina Calero Ruiz, especialista en escultura, para explicar las patologías y las posibles propuestas de tratamiento. De común acuerdo se definieron los criterios a seguir, llegando a la conclusión de que había que resolver los importantes problemas estructurales y proceder, entre otras cosas, a la eliminación de los repolicromados del busto. Las carnaciones tendrían un tratamiento sujeto a la retirada de repintes, manchas y alteraciones superficiales. La definición de estos criterios permitió substraer las partes descompuestas e inestables para respetar formas muy reconocibles ya implantadas en la memoria colectiva.

Con los resultados de las analíticas se planteó abrir dos catas en escalera para comprobar en dos zonas distantes su coherencia. Se comenzó a trabajar en la espal$\mathrm{da}$, retirando las gruesas capas de yeso y clavos que rodeaban todo el busto. Desde 


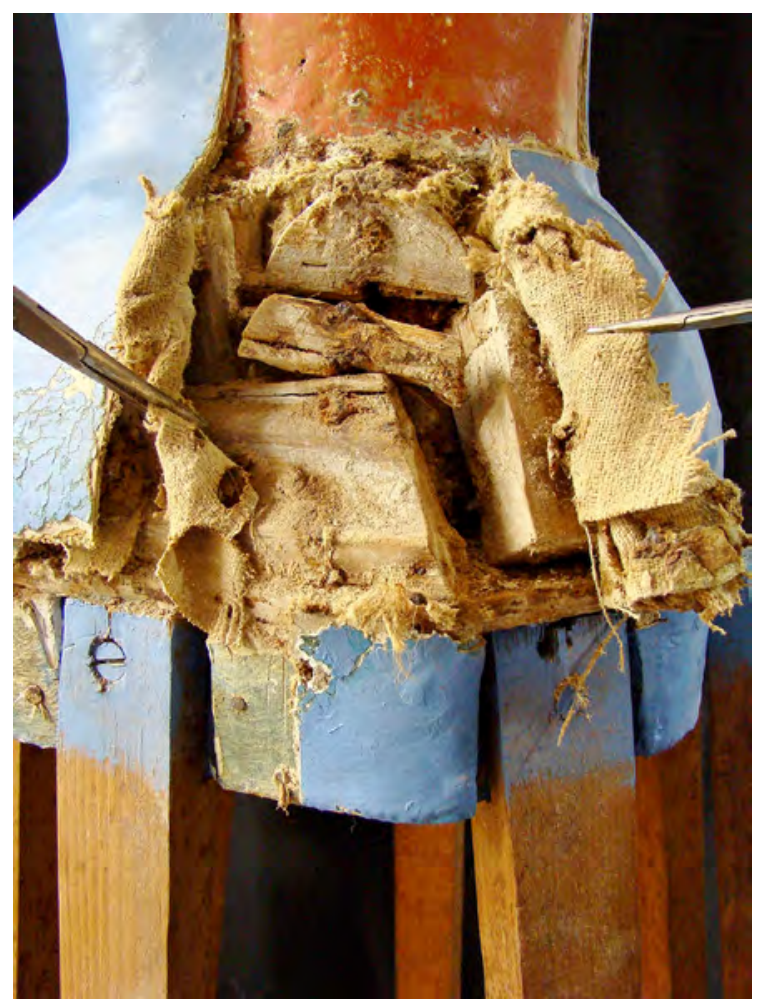

Foto 5. Materiales heterogéneos no originales.

allí se descendió hasta la cadera, poniendo al descubierto una masa heterogénea de maderas, clavos, yeso y trapos, hallándose bajo estos desechos el soporte original completamente decapado. Liberada toda la cadera de este material, se descubrió que la escultura se soportaba únicamente por tres tornillos corroídos y que por lo tanto ya no tenía sostén estructural. Se propuso conformar un nuevo volumen de cadera, conectado al nuevo candelero de madera ensamblada y encolada, que diera forma a esta zona y le aportara seguridad para acomodar correctamente su indumentaria.

Se desmontaron los brazos descubriendo la fractura de una de las articulaciones y el bloqueo de otra con un tornillo moderno, lo que nos llevó a la reposición de ambas, pero con otro planteamiento. Aprovechando los orificios originales se colocaron dos pasadores de giro de madera de morera, devolviendo de este modo la movilidad completa a las zonas, tal y como era originalmente. Todos los orificios y perforaciones causados por tornillos y clavos de restauraciones anteriores se resanaron con espigas de madera de pinsapo encoladas con acetato de polivinilo. La escultura del Niño Jesús se fue trabajando de modo paralelo, empezando por retirar bajo lupa binocular los importantes repintes, que ocultaban unas carnaciones bien conservadas, aunque con daños por erosión, causados principalmente por joyas. 


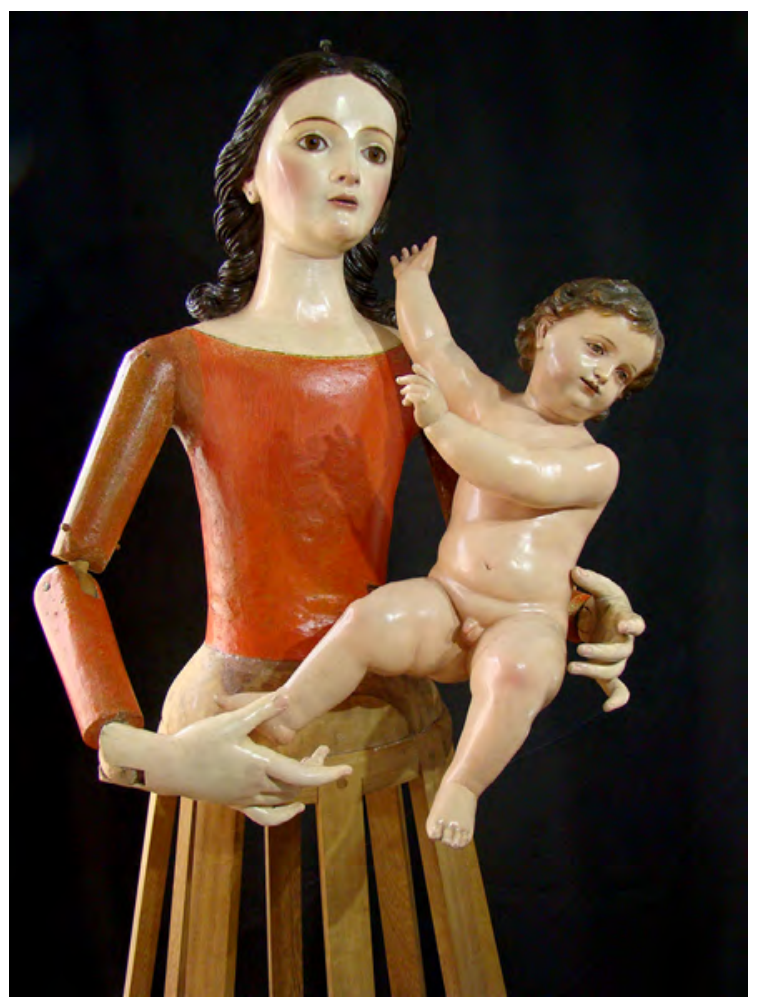

Foto 6. Restauración finalizada.

Este proceso dejó a la vista varios dedos de yeso y de madera, colocados y repintados en restauraciones sucesivas. Ante su poca estabilidad y desproporción se decidió eliminarlos y reponerlos a partir de una espiga de madera de cedro recubierto de Araldit $H V$ y $S V 427$. Una vez seco este recubrimiento se tallaron nuevamente, encolando y ensamblando cada elemento en varios orificios practicados al efecto. Tras la reconstrucción de elementos perdidos se reintegraron las lagunas de preparación tanto en el Niño como en la escultura principal. Para ello se aplicó un estuco compuesto por colas naturales y sulfato de calcio en caliente en distintos grados de consistencia, al que se le añadió Nipagin sódico al 2\%. Una vez seco se rebajó y alisó convenientemente para adaptar las superficies.

La reintegración de color constituyó la fase final y más delicada del trabajo. Aquí empleamos colores de restauración Gamblin, siguiendo dos criterios de reintegración combinados: rayado y punteado por veladura. Hemos tenido en cuenta que esta escultura tiene carácter procesional. Se ha tratado de ajustar el tono entre la materia original y la reintegrada, evitando cualquier tipo de distorsión cromática o de textura. Se han dejado sin retocar algunos desgastes, craquelados y huellas del pasado para no incidir negativamente en las cualidades que el paso del tiempo 
le ha aportado. Finalmente se aplicó una protección de barniz Winsor \& Newton pulverizado, dejando 48 horas de intervalo entre capas para un secado homogéneo.

Previo al traslado de la obra a su parroquia se hizo una prueba de vestuario, aprovechando la ocasión para orientar a los responsables de la misma en cuestiones de mantenimiento y manipulación de cara a su conservación futura.

\section{JOYERO Y AJUAR TEXTIL}

Desde muy temprano y tras la conquista de las Islas Canarias la veneración mariana hizo posible que cada isla tomara por patrona protectora a una imagen de la Virgen. Algunos de estos iconos, inicialmente esculturas de bulto enteramente policromadas, se fueron dotando de un ajuar, que el pueblo, por devoción y vanidad, les regalaba. Tal fue el afecto a María que en cada localidad donde se fundaba una parroquia se procuraba revestir a su titular de toda la majestad posible. A esto debemos sumar los milagros atribuidos, que muy pronto derivaron en valiosos regalos ofrecidos por sus camareras o devotos. Desgraciadamente, el devenir histórico, la codicia y la delicada naturaleza, especialmente de los textiles, han hecho que hoy en muchos casos conservemos memoria de estos objetos en las fuentes documentales y por referencia plástica en el arte de la pintura y la fotografía.

Nuestra Señora de la Peña de Francia, patrona y titular de su parroquia, no quedó desmarcada de este fenómeno, precisamente en un puerto que durante buena parte de los siglos XVII y XVIII gozó de holgura económica gracias al comercio. Los sucesivos inventarios de alhajas que se han conservado pueden medir su extendida devoción en el tiempo y detallar en materia su alcance y riqueza.

Dentro de la amplia relación de joyas y vestidos destacan varias prendas que milagrosamente se han conservado. La primera de ellas es un colgante de ámbar, una joya-amuleto especialmente interesante, elaborado a partir de dos núcleos sin pulir, unidos entre sí por un pasador. Se abrazan por engarces flordelisados de oro de 18 quilates, que van guarnecidos de ocho cabujones de esmeraldas muy puras y cincuenta y una perlas naturales. Podría datarse en el primer cuarto del siglo XVIII, sin que podamos por ahora determinar ni su origen ni su donante con certeza, $y$, pese a que en el catálogo de la exposición $L a$ Casa Indiana ${ }^{20}$ se afirma haber sido la poetisa cubana Dulce María Loynaz Muñoz quien la regalara, discrepamos de esta afirmación, pues se conoce la existencia de esta prenda desde el siglo XVIII, tal y como se confirma en el primer inventario del año 1772, donde se puede leer: «Por una poma de ámbar guarnecida de oro, perlas y esmeraldas, pesa ocho adarmes $»^{21}$. Salvando distancias y sin atribuirle esta procedencia, su morfología nos evoca al-

${ }^{20}$ La Casa Indiana. Platería doméstica y artes decorativas en La Laguna. Edit. Excelentísimo Ayuntamiento de San Cristóbal de La Laguna. Concejalía de Patrimonio Histórico-Artístico. 2017. p. 43.

${ }_{21}$ Archivo Histórico Diocesano La Laguna (en adelante AHDLL). Cofradía de Nuestra Señora de la Peña de Francia. Inventarios y cuentas 1746/1888. Doc. 4 Inventario de Alhajas año 1772. 


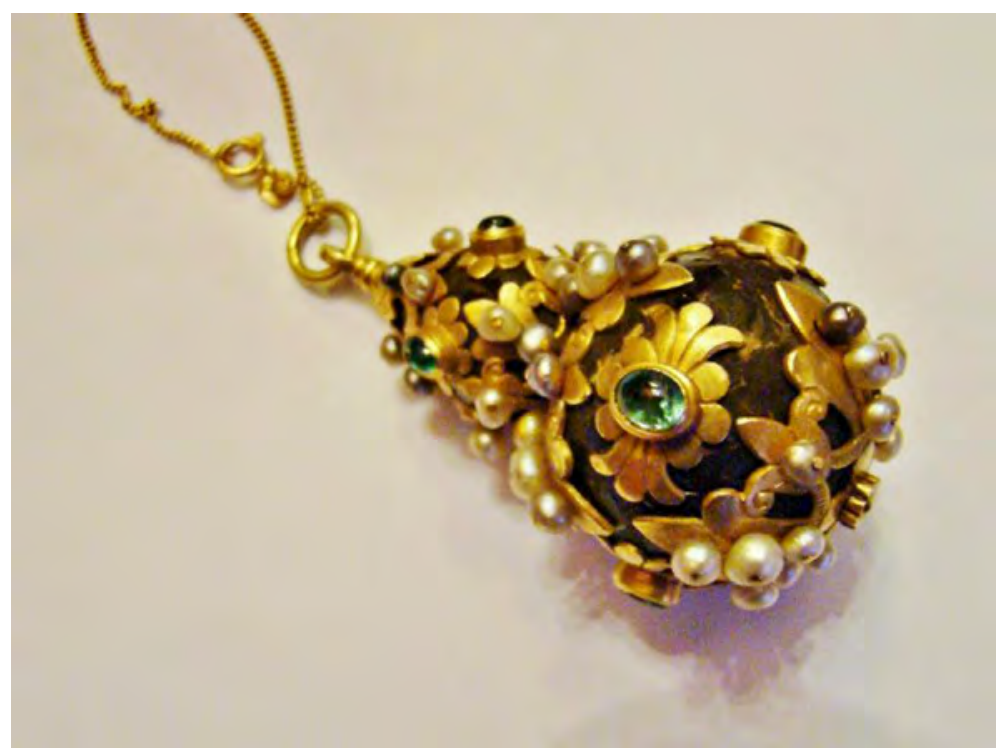

Foto 7. Poma de ámbar. s. XviII.

gunos colgantes del siglo Xvi de entre los cuales destaca el iluminado en el libro de joyas de Albrecht $\mathrm{V}$ y de su esposa Anna, duques de Baviera ${ }^{22}$, un modelo de partida muy sugerente, que conecta con colgantes hallados en otros joyeros de esta misma tipología, que incluyen también bezoares.

Otra joya interesante y que ha pasado desapercibida hasta ahora es un colgante de doble cara a modo de creciente lunar de oro, esmaltes verde, rojo y blanco y guarnecido de perlas naturales, que se cita por primera vez en el inventario de $1831^{23}$. La pieza ha llegado a nuestros días muy mutilada, y su análisis revela que debió ser una prenda más compleja y rica debido al número de argollas libres y engarces vacíos que muestra. Por su técnica podría tratarse de una pieza de transición entre los siglos XVII y XVIII, época en la que empiezan a quedar anticuados los esmaltes, que tanto aprecio estético tuvieron en siglos pretéritos.

Asimismo, en el inventario de 1888 se cita otra pieza interesante, concretamente un dije de oro de 18 quilates, combinado con esmaltes, que conforman un ojo. Joyas de este tipo asocian el valor crematístico y ornamental con el mágico-

${ }^{22}$ Este libro inventario de joyas fue iluminado por Hans Mielich 1516 -1573 y se conserva en la Bayerische Staatsbibliothek München, Baviera, Alemania.

${ }_{23}$ AHDLL. Cofradía de la Peña de Francia. Inventarios y cuentas 1746/1888. Inventario de alhajas de Nuestra Sra. de la Peña de Francia que existen, pertenecientes al uso de dicha imagen. Un folio: «Una alhaja de oro con perlas grandes y un medalloncito o almendrón encasquillado en oro y su alfiler de pecho con una esmeralda orlada de perlas». 
religioso, convirtiéndose en verdaderos amuletos protectores. No son escasos los ejemplos bien documentados de higas, ramas de coral o cascabeles, cuyo fin primordial era alejar la enfermedad, el dańo o el dolor en la infancia. Quizá debido a este significado haya quedado vinculada esta pequeña prenda al Niño Jesús de nuestra imagen, que la luce en el pecho o en una cadena solo cuando procesiona por las calles portuenses.

Los inventarios consultados también arrojan algo de luz sobre algunas prendas textiles, que se conservan aún, aunque el panorama en este apartado es muy desalentador, pues el abandono, sumado a la delicada naturaleza de los textiles, han hecho su trabajo. Concretamente la parroquia conserva en su museo un traje completo, que podría coincidir con el descrito en su inventario, y que la suerte ha hecho que haya llegado hasta hoy "por otro de lampaso encarnado con encaje de oro viejo». Un elegante ejemplo de confección en seda e hilos de oro con rameados florales en rosa, azul y verde. Este traje completo permaneció durante mucho tiempo olvidado en dependencias parroquiales, hasta que encontró acomodo entre las vitrinas del museo.

La titular portuense conserva otro rico traje, originalmente bordado sobre un género de seda de color rosa, que fue traspasado a un nuevo fondo hacia mediados del siglo xx. Esta delicada confección, que ha pasado completamente desapercibida, muestra un desarrollo decorativo de gran virtuosismo expresado en la variedad de puntos, selección cromática y diseño, que repite de modo rítmico reservas florales de intrincado dibujo. Aunque no llegamos a identificarlo en el inventario de 1772, Ruiz Álvarez afirma que fue bordado en el siglo XviII ${ }^{24}$ por las monjas del cercano convento de Nuestra Señora de las Nieves. Con este vestido procesionó en agosto de 1958, luciendo elegantemente sobre sus espaldas otro textil singular, que regaló la poetisa cubana Dulce María Loynaz Muñoz ${ }^{25}$. Nos referimos a un delicado manto de moaré bordado, que alude simbólicamente a la entrelazada unión de la isla de Cuba y el Puerto de la Cruz, en la que se vinculan las flores y heráldicas de ambos lugares. Esta joya textil se expone de modo deplorable en la parroquia portuense, sin que se llegue a entender que al valor material, técnico y simbólico de sus bordados va unida la grandeza y generosidad de su donante, que un día decidió hacernos este regalo.

${ }^{24}$ Ruiz Álvarez, Antonio: «Estampas Históricas del Puerto de la Cruz. La Peña de Francia». Periódico La Tarde, 19 de agosto de 1949. p. 3. Restaurado por la señorita Delfina Rodríguez y Rodríguez...

${ }^{25}$ Loynaz Muñoz, Dulce María: Un verano en Tenerife. Edit: Viceconsejería de Cultura y Deportes del Gobierno de Canarias. 1992, Capitulo XXIII, p. 311. El Puerto de la Cruz. «... No sé, pero un buen día decidí que su patrona celestial que es la Virgen de la Peña de Francia, tuviera un nuevo manto y que ese manto fuera un manto cubano. En Cuba, pues, lo hice bordar porque así fuera, no por desconocer todo el primor que la mujer canaria pone en sus labores manuales; pero a fe que tampoco mis cubanas se quedaron atrás en tal empeño y de mucha alegría me sirvió que se admirara su destreza en tierra donde calados y bordados tienen la admiración del mundo. De seda azul oscuro, recamado de mariposas blancas - nuestra flor nacional-y de rojos claveles espańoles que se entrelazan a la nívea flor, llegó por fin una mañana alegre, que lo fue de gran fiesta para los hijos del Puerto...». 
Detrás del hecho de vestir y desvestir imágenes existía un ritual privado exclusivo en Canarias de mujeres virtuosas, normalmente viudas o solteras, de alto rango social, que eran las encargadas de custodiar y disponer del ajuar de vestidos y joyas de la Virgen. El cambio de vestuario era constante y se relacionaba directamente con la liturgia del ańo y no únicamente con un día seńalado como ocurre hoy. Para ello se confeccionaron trajes, mantos, rostrillos, fajas... de delicadas labores generalmente en soporte de seda, pero labradas con hilos de oro o plata, a los que se aplicaban ricos encajes o perlas, de las que han quedado amplias referencias en las fuentes archivísticas consultadas.

El cambio constante de vestuario se aprovechaba, entre otras cosas, para solicitar la intercesión sagrada de María para curar a algún enfermo, favorecer el buen parto, un buen viaje, trabajo o fortuna económica. En ocasiones estas plegarias o ruegos tenían forma escrita, fijándose con alfileres en las enaguas o mantos. Pocos de estos ruegos se han conservado debido a su carácter temporal y efímero, no así otros que fueron introducidos en el cuerpo de las esculturas a través de alguna fisura, y que en algunos casos se han podido recuperar durante procesos de conservación.

Especial valor dentro del antiguo exorno de la patrona portuense lo ocuparon las labores de platería, que enriquecieron su exposición pública en las grandes festividades. Nos hemos de referir en primer lugar a las andas procesionales, que se conservaron intactas hasta mediados del siglo pasado y de las cuales hoy solo perviven algunos fragmentos. Morfológicamente se componían de un templete sustentado por pilares abalaustrados sobre plintos calados, que descansaban sobre una basa mixtilínea. Fue un trabajo programado en el tiempo, que combinaba almas de carpintería con delicados repujados en plata y que por razones supuestamente de índole económica nunca se llegaron a culminar. Para su factura se fundió el metal de otras, de que se servía la Peña de Francia y el Gran Poder de Dios ya antes de 1746 , y que se fue completando con aportaciones sucesivas. Como era costumbre, las andas se enriquecían con otros elementos extraíbles, en este caso con una aureola de ráfagas y una luna. Precisamente este símbolo indisolublemente mariano fue objeto de codicia, al ser robado en el año 1747, pagándose 200 reales a un anónimo platero para que hiciera una nueva ${ }^{26}$. Suponemos que ha de tratarse de la misma que luce la Virgen actualmente en su retablo y recorridos procesionales.

El ajuar de la titular portuense lo completan tres magníficas coronas de plata calada y afiligranada, una de ellas sobredorada, que han sido estudiadas en profundidad por Jesús Pérez Morera, quien defiende desde un punto de vista técnico que la combinación de plata calada y filigrana es característica definitoria de un origen cubano, con mayor razón si los ejemplares portuenses se comparan con similares

${ }^{26}$ AHDLL Cofradía de La Peña de Francia. Inventarios y Cuentas 1746-1888. Descargo de las Cuentas que da don Pablo Pérez del Castillo, Presbítero como Mayordomo de la Cofradía de Ntra. Sra. de la Peńa de Francia de este Puerto de la Orotava. 1747 fol. 1: «Se pagaron 200 reales al platero que fabricó la luna que hurtaron a la Virgen». 
de origen confirmado, como la corona de filigrana del santuario de Nuestra Señora de las Angustias en los Llanos de Aridane (La Palma).

Todos estos bienes fueron testimonio de una devoción arraigada en el Puerto de la Cruz con repercusión en otros municipios cercanos como Los Realejos, La Orotava o San Juan de la Rambla, de donde procedían muchos de los hermanos y hermanas. Hoy su culto ha quedado muy menguado, atendido por una cofradía pequeña pero unida por el carińo y respeto a la Virgen, y lo que antaño ocupó varios días de celebraciones con actos religiosos y civiles ha quedado relegado a una procesión y poco más.

Con este trabajo queremos contribuir a la recuperación de la memoria perdida y poner nuevamente en valor una de las más antiguas manifestaciones culturales y religiosas del valle de La Orotava: el culto y las fiestas a Nuestra Señora de la Peña de Francia. 